\title{
EVALUATION OF GROWTH AND YIELD OF SWEET PEPPER (CAPSICUM $A N N U U M)$ VARIETIES UNDER NET PROTECTED CONDITIONS
}

\author{
M. S. Islam ${ }^{1}$, A. Akter ${ }^{2}$, M. Z. Akhi ${ }^{3}$ and B. Debnath ${ }^{4}$
}

\begin{abstract}
An experiment was conducted at the experimental field of Horticulture Department, Sylhet Agricultural University, Bangladesh during winter season of 2013-2014 to evaluate growth and yield of sweet pepper varieties under net protected condition. The two-factor experiment was laid out in Randomized Complete Block Design with three replications. Three popular sweet pepper varieties viz. BARI Mistimorich-1, California Wonder and Yolo Wonder were grown under three protected systems viz. fine net (120 mesh), coarse net (40 mesh) and open field. Considering the effect of varieties, the highest value for all the parameters viz. fruit length $(10.01 \mathrm{~cm})$, fruit diameter $(5.90$ $\mathrm{cm})$, number of fruits/plant (13.61), fruit yield per plant $(0.77 \mathrm{~kg})$, fruit yield $(21.31 \mathrm{t} / \mathrm{ha})$ were found in California Wonder followed by BARI Mistimorich-1 and Yolo Wonder. Again, considering the effect of net protection system, maximum values for parameters viz. early flowering, fruit length $(10.58 \mathrm{~cm})$, fruit diameter $(6.29 \mathrm{~cm})$, number of fruits/ plant (16.14), fruit yield/plant $(0.94 \mathrm{~kg})$ and per hectare $(26.86 \mathrm{t} / \mathrm{ha})$ were recorded under fine net protection system. Under fine net covering plants produced better quality fruit than open field condition. The earliest flowering (60.67 days), the highest number of fruits per plant (19.18) and the maximum fruit yield (35.71 t/ha) were observed in BARI Mistimorich-1 grown under fine net system followed by California Wonder grown under coarse net protected system. Benefit cost ratio (BCR) for fine net (5.28) and coarse net (6.75) protected system were much higher than that of open field (1.64) condition indicating bright future for sweet pepper cultivation under net protected system.
\end{abstract}

Keywords: Sweet pepper, protected cultivation, fine net, variety, fruit yield.

\section{Introduction}

Sweet pepper (Capsicum annuum L. 2n = 24) belongs to the family Solanaceae is an important nutritious vegetables grown extensively in almost every countries especially temperate countries of the world (Greenleaf, 1986). It is believed to be originated in tropical South America, after that introduced by the Portuguese in India and distributed throughout the tropical and sub-tropical countries of the world (Shoemaker and Teskey, 1955). Sweet pepper is popularly known as bell pepper or capsicum and may be eaten as cooked, raw as well as salad. Capsicum is rich in vitamin C, vitamin A, carbohydrates, proteins, fiber, unsaturated fatty acid (Lal et al., 2014; Zende, 2008) and also known as medicinal plants due to having capsaicin, capsanthin, carotinoids and antioxidantal properties (Aminifard et al., 2012). This crop is well adapted to

1, 3 \& 4 Department of Horticulture, Sylhet Agricultural University, Sylhet, Bangladesh. ${ }^{2}$ Department of Agricultural Science, Comilla Govt. College, Cumilla, Bangladesh. *Corresponding author: shahidulhrt@gmail.com 
temperature ranged from $16-25^{\circ} \mathrm{C}$. This is very sensitive to environmental factors viz. both biotic and abiotic factors (Bhatt et al., 1992). Fruit setting is largely affected by high temperature at night than day temperature. On the contrary, blossom dropping also occurred at below $16^{\circ} \mathrm{C}$ night temperature and above $32^{\circ} \mathrm{C}$ day temperature (Rylski and Spigelman, 1982; Boswell, 1964). In Bangladesh, from December to January night temperature is gradually decreased below $10^{\circ} \mathrm{C}$ or less which is detrimental to both vegetative and fruiting stage of sweet pepper. Again severe powdery mildew and mite infestation are common for plants when subjected to longer periods of temperatures between 10 to $15^{\circ} \mathrm{C}$ and daytime RH between 85 to $95 \%$ (Elad et al., 2007). Among various agronomic practices, proper vegetative and reproductive growth as well as optimum yield can be ensured using protected net covering (Jeon and Chung, 1982). Shaded nets could potentially alter the crop's physiological and biochemical processes, metabolite profiles and ultimately growth, development, yield and quality (Ilic et al., 2017). For instance, photoselective nettings have been shown to influence the biosynthesis of bioactive compounds in sweet peppers (Mashabela et al., 2015; Selahle et al., 2015). These also provide protection against disease, pest infestation and cold injury as night temperature can be increased inside the net than outside (Shahak, 2008). Sweet pepper is a high value crop and its demand is increasing day by day. But all the varieties may not perform equally in all regions of Bangladesh. So, to meet the growing demand and to increase the export potentiality BARI Mistimorich-1, California Wonder and Yolo Wonder are popularly growing in our country.
In the near past no intervention was taken to evaluate sweet pepper varieties or production technologies at Sylhet region. Considering the facts, the present study was undertaken to evaluate three promising sweet pepper varieties under three different net protection systems in Sylhet.

\section{Materials and Methods}

The present study was conducted at the experimental field of Horticulture Department, Sylhet Agricultural University, Sylhet, during winter season of 2013-2014. This experimental area belongs to the "Khadimnagar" soil series of Eastern Surma-Kushiara Floodplain under the Agro ecological Zones-20 (FAO, 1988). The two-factor experiment was laid out in a randomized complete block design with three replications. Factor one consisted of three popular sweet pepper varieties viz. $\mathrm{V}_{1}=$ BARI Mistimorich-1, $\mathrm{V}_{2}=$ California Wonder and $\mathrm{V}_{3}=$ Yolo Wonder and the other factor having three protection systems viz. $\mathrm{P}_{1}=$ fine net (120 mesh), $\mathrm{P}_{2}=$ coarse net (40 mesh) and $\mathrm{P}_{3}=$ open field. Seeds of all the varieties were sown in the seedbed on 15 October 2013. After germination, seedlings having around 2-3 true leaves were transplanted in poly bags. Then, 35-day-old seedlings having 4-5 true leaves were transplanted in the experimental plots. In each plot there were two rows accommodating 8 plants per row. The size of unit plot was $3.2 \mathrm{~m} \times 1.0 \mathrm{~m}$ and $60 \times 40 \mathrm{~cm}$ spacing was maintained. The height of the net protection structure was around 1.0 meter. Each plot was fertilized with well decomposed cowdung, urea, triple super phosphate (TSP), muriate of potash (MoP), gypsum and $\mathrm{ZnO}$ at the rate of 10 ton, $220 \mathrm{~kg}, 330 \mathrm{~kg}, 200 \mathrm{~kg}, 110 \mathrm{~kg}$ and $5 \mathrm{~kg}$ per hectare, respectively (Rashid et al., 2006). Half of the quantity of cow dung was applied 
at final land preparation. The rest amount of cowdung, entire quantity of TSP, ZnO, gypsum and one third each of urea and MoP were applied during pit preparation and remaining urea and MoP were applied in two equal splits at 25 and 50 days after transplanting as top dressed. Irrigation, weeding, mulching, staking, etc. were done as and when required. Data were recorded on different parameters viz. days to flowering, fruit length $(\mathrm{cm})$, fruit diameter $(\mathrm{cm})$, number of fruits /plants, individual fruit weight $(\mathrm{g})$, fruit yield/plant $(\mathrm{kg})$ and total fruit yield $(\mathrm{t} /$ ha) to evaluate the effect of both varieties and net protected cultivation system. Then recorded data were compiled and statistically analyzed using MSTAT-C software. Economic analysis was done to compare the feasibility of sweet pepper cultivation under open field and or net protected condition.

\section{Results and Discussion \\ Main effect of varieties}

All the parameters were significantly affected due to varieties except days to flower and fruit size (Table 1).

\section{Days to flowering}

The earliest flowering was recorded in BARI Mistimorich-1 (64.44 days) similar to that of California Wonder (64.77 days). On the other hand, the late flowering was recorded in Yolo Wonder (65 days). This finding is at par with that of Anon (2010) where days to flowering varied from 66 to 69 days among four sweet pepper inbred lines.

\section{Fruit length (cm)}

It was not significantly affected due to varieties. However, the highest fruit length was found in California Wonder $(10.01 \mathrm{~cm})$ and the lowest in Yolo Wonder $(9.22 \mathrm{~cm})$. Among eight sweet pepper inbred lines it ranged from 6.40 to $8.12 \mathrm{~cm}$ as was reported by Anon (2009).

\section{Fruit diameter (cm)}

Variation in fruit diameter was not found. However, the highest fruit diameter was measured at California Wonder $(5.90 \mathrm{~cm})$ while the lowest was observed in Yolo Wonder $(5.58 \mathrm{~cm})$ which was closely related to BARI Mistimorich-1 $(5.83 \mathrm{~cm})$.

Table 1. Effect of sweet pepper varieties on yield and yield attributes

\begin{tabular}{lccccccc}
\hline Genotype & $\begin{array}{c}\text { Days to } \\
\text { flowering }\end{array}$ & $\begin{array}{c}\text { Fruit length } \\
(\mathrm{cm})\end{array}$ & $\begin{array}{c}\text { Fruit } \\
\text { diameter } \\
(\mathrm{cm})\end{array}$ & $\begin{array}{c}\text { Number of } \\
\text { fruits/plant }\end{array}$ & $\begin{array}{c}\text { Individual } \\
\text { fruit weight } \\
(\mathrm{g})\end{array}$ & $\begin{array}{c}\text { Fruit yield/ } \\
\text { plant }(\mathrm{kg})\end{array}$ & $\begin{array}{c}\text { Fruit yield } \\
(\mathrm{t} / \mathrm{ha})\end{array}$ \\
\hline $\mathrm{V}_{1}$ & 64.44 & 9.32 & 5.83 & $12.07 \mathrm{~b}$ & $58.82 \mathrm{a}$ & $0.71 \mathrm{~b}$ & $20.38 \mathrm{~b}$ \\
$\mathrm{~V}_{2}$ & 64.77 & 10.01 & 5.90 & $13.61 \mathrm{a}$ & $56.58 \mathrm{a}$ & $0.77 \mathrm{a}$ & $21.31 \mathrm{a}$ \\
$\mathrm{V}_{3}$ & 65.00 & 9.22 & 5.58 & $11.94 \mathrm{~b}$ & $49.41 \mathrm{~b}$ & $0.59 \mathrm{c}$ & $16.86 \mathrm{c}$ \\
F-test & $\mathrm{ns}$ & $\mathrm{ns}$ & $\mathrm{ns}$ & $* *$ & $* *$ & $* *$ & $*$ \\
$\mathrm{CV} \%$ & 2.47 & 6.78 & 8.85 & 4.81 & 6.71 & 3.92 & 5.35 \\
\hline
\end{tabular}

Means followed by same letter(s) in a column do not differ significantly by LSD

$* *=$ Significant at $1 \%$ level of probability, $*=$ Significant at $5 \%$ level of probability, ns= Not significant, $\mathrm{V}_{1}$, $\mathrm{V}_{2}$ and $\mathrm{V}_{3}$ indicate BARI Mistimorich-1, California Wonder and Yolo Wonder, respectively. 


\section{Number of fruits /plant}

Number of fruit per plant was significantly influenced by three different sweet pepper varieties (Table 1). Maximum number of fruits per plant was found in California Wonder (13.61) followed by BARI Mistimorich-1 (12.07) while it was found the lowest in Yolo Wonder (11.94). Sattar et al. (2018) reported that the number of fruits per plant was significantly differed from 5.07 to 22.97 among eight sweet pepper inbred lines.

\section{Individual fruit weight (g)}

The highest individual fruit weight was observed in BARI Mistimorich-1 (58.82 g) followed by California Wonder (56.58 g). The lowest fruit weight was found in Yolo Wonder (49.41 g). Anon (2010) found variable individual fruit weight (65-77 g) among eight sweet pepper inbred lines.

\section{Fruit yield/plant (kg)}

The maximum fruit yield was noticed in California Wonder $(0.77 \mathrm{~kg})$ followed by BARI Mistimorich-1 (0.71 kg). But the minimum yield was found in Yolo Wonder $(0.59 \mathrm{~kg})$. Similar variation in fruit yield among several sweet pepper genotypes was noticed by other researchers (Anon, 2010; Sattar et al., 2018) when grown at Gazipur.

\section{Fruit yield (t/ha)}

Fruit yield per hectare varied significantly among the varieties. It ranged from $16.86 \mathrm{t}$ to $21.31 \mathrm{t}$. Maximum fruit yield was found in California Wonder (21.31 t/ha) followed by BARI Mistimorich-1 (20.38 t/ha) and it was minimum in Yolo Wonder (16.86 t/ha). It might be due to the genetical factors of the variety concerned. Differential yield (9.70 -29.09 t/ha) was also recorded by Sattar et al. (2018) when studied with eight sweet pepper inbred lines.

\section{Main effect of net protections}

Significant variation was observed for all the parameters under study due to net protection system (Table 2).

\section{Days to flowering}

The earliest flowering was observed in plant grown under fine net (61days) followed by coarse net and open field (66.00 days) condition. Days to flowering was differed when plants were grown under different protective systems as was reported by Halim and Islam (2013).

Table 2. Main effect of net protections on yield and yield attributes of sweet pepper

\begin{tabular}{lccccccc}
\hline Net protection & $\begin{array}{c}\text { Days to } \\
\text { flowering }\end{array}$ & $\begin{array}{c}\text { Fruit } \\
\text { length } \\
(\mathrm{cm})\end{array}$ & $\begin{array}{c}\text { Fruit } \\
\text { diameter } \\
(\mathrm{cm})\end{array}$ & $\begin{array}{c}\text { Number of } \\
\text { fruits/ plant }\end{array}$ & $\begin{array}{c}\text { Individual fruit } \\
\text { weight }(\mathrm{g})\end{array}$ & $\begin{array}{c}\text { Fruit yield/ } \\
\text { plant }(\mathrm{kg})\end{array}$ & $\begin{array}{c}\text { Fruit yield } \\
(\mathrm{t} / \mathrm{ha})\end{array}$ \\
\hline $\mathrm{P}_{1}$ & $61 \mathrm{~b}$ & $10.58 \mathrm{a}$ & $6.29 \mathrm{a}$ & $16.14 \mathrm{a}$ & $58.24 \mathrm{~b}$ & $0.94 \mathrm{a}$ & $26.86 \mathrm{a}$ \\
$\mathrm{P}_{2}$ & $66 \mathrm{a}$ & $9.96 \mathrm{a}$ & $5.71 \mathrm{ab}$ & $13.55 \mathrm{~b}$ & $63.47 \mathrm{a}$ & $0.86 \mathrm{~b}$ & $24.07 \mathrm{~b}$ \\
$\mathrm{P}_{3}$ & $66 \mathrm{a}$ & $8.02 \mathrm{~b}$ & $5.31 \mathrm{~b}$ & $7.94 \mathrm{c}$ & $32.74 \mathrm{c}$ & $0.26 \mathrm{c}$ & $7.62 \mathrm{c}$ \\
$\mathrm{F}-\mathrm{test}$ & $* *$ & $* *$ & $* *$ & $* *$ & $* *$ & $* *$ & $* *$ \\
$\mathrm{CV} \%$ & 2.47 & 6.78 & 8.85 & 4.81 & 6.71 & 3.92 & 5.35 \\
\hline
\end{tabular}

Means followed by same letter(s) in a column do not differ significantly by LSD

$*=$ Significant at $1 \%$ level of probability, $\mathrm{P}_{1}, \mathrm{P}_{2}$ and $\mathrm{P}_{3}$ indicate fine net, coarse net and open field, respectively. 


\section{Fruit length (cm)}

The highest fruit length was measured in plant grown under fine net $(10.58 \mathrm{~cm})$ while it was the lowest in open field condition (8.02 $\mathrm{cm})$. This result was also well supported with the findings of Halim and Islam (2013). For instance nettings have been shown to influence the

biosynthesis of bioactive compounds in sweet peppers (Mashabela et al., 2015; Selahle et al., 2015) which ensure growth and development of the plant. In the present study fruit growth in relation to length and diameter was significantly higher than control plot.

\section{Fruit diameter (cm)}

The highest fruit diameter was observed the plant growing under fine net system $(6.29 \mathrm{~cm})$ followed by coarse net $(5.71 \mathrm{~cm})$ while it was the lowest in open field $(5.31 \mathrm{~cm})$. Under fine net covering plant might attain desirable fruit size for having congenial growing condition.

\section{Number of fruits /plant}

The highest number of fruits per plant was observed in plants protected with fine net (16.14) followed by the coarse net (13.55) while it was the lowest in open field (7.94) condition. The present findings are in line with the findings of Paul (2009). Islam and Halim (2014) also reported variation in number of fruits per plant when California Wonder was grown under four different tunnel covers made on polyethylene and nylon net.

\section{Individual fruit weight (g)}

Maximum individual fruit weight was found for course net (63.47 g) which was followed by fine net $(58.24 \mathrm{~g})$ and minimum was found for open field (32.74 g). Individual fruit weight was lower in fine net than course net. These might be due to producing more number of fruits per plant in fine net. This finding is closely related to the findings of Paul (2009), Islam and Halim (2014). Ilic et al. (2017) reported that pericarp fruit thickness was significantly higher in peppers grown under red net house and black net house compared to the open field which might determine the fruit weight.

\section{Fruit yield /plant (kg)}

Significant variation in case of fruit yield per plant was found due to the main effect of different net protection system (Table 2). The maximum fruit yield was observed from fine net $(0.94 \mathrm{~kg})$ while it was the lowest in open field $(0.26 \mathrm{~kg})$. Plants of coarse net protection system produced $0.86 \mathrm{~kg} /$ plant. Fruit yield depends on total number of fruits and fruit size. In the present study plants grown under net protected condition produced higher number and heavier fruits caused higher yield than that of open field. These result had the harmony with the study done by Wien et al. (1989) and Islam and Halim (2014).

\section{Fruit yield (t/ha)}

Fruit yield under different protection systems ranged from 7.62 to $26.86 \mathrm{t} / \mathrm{ha}$. The plant grown in fine net protection yielded maximum closely followed by the coarse net protection (24.07 t/ha), while it was minimum in open field.

\section{Interaction effect between varieties and net} protections on yield and yield attributes

Interaction effect between varieties and net protection was found significant for all the parameters except days to flowering and fruit diameter (Table 3). 


\section{Days to flowering}

Though almost similar number of days was required for flowering for all treatment combinations, the earliest flowering (60.67 days) was observed in BARI Mistimorich-1 planted in fine net protection system followed by the California Wonder and Yolo Wonder (61.67 days) when grown in fine net protection system. The late flowering was recorded from BARI Mistimorich-1 and Yolo Wonder (67.33 days) planted in coarse net protection system.

\section{Fruit length (cm)}

Fruit length was significantly differed among the nine different treatment combinations (Table 3) due to the combined effect of varieties and net protection system. Among the treatment combinations, the highest fruit length $(11.20 \mathrm{~cm})$ was observed in BARI Mistimorich-1 planted in fine net protection. The second highest fruit length was recorded in
Yolo Wonder planted in coarse net protection system $(11.07 \mathrm{~cm})$ which was statistically identical to California Wonder planted in fine net system $(10.37 \mathrm{~cm})$. The lowest fruit length $(6.43 \mathrm{~cm})$ was recorded from Yolo Wonder planted in open field. Result suggested that fruit length might be influenced by both varieties and different net protection system.

\section{Fruit diameter (cm)}

Fruit diameter of different treatment combinations ranged from 4.67 to $6.37 \mathrm{~cm}$ being the highest in California Wonder planted in fine net protection system while the lowest was recorded in Yolo Wonder planted in open field.

\section{Number of fruits/plant}

Among the treatment combinations, the highest number of fruits per plant was observed in BARI Mistimorich-1 grown

Table 3. Interaction effect between varieties and net protection system on yield and yield attributes of sweet pepper

\begin{tabular}{lccccccc}
\hline Treatment & $\begin{array}{c}\text { Days to } \\
\text { flowering }\end{array}$ & $\begin{array}{c}\text { Fruit length } \\
(\mathrm{cm})\end{array}$ & $\begin{array}{c}\text { Fruit } \\
\text { diameter } \\
(\mathrm{cm})\end{array}$ & $\begin{array}{c}\text { Number of } \\
\text { fruits/ plant }\end{array}$ & $\begin{array}{c}\text { Individual } \\
\text { fruit weight } \\
(\mathrm{g})\end{array}$ & $\begin{array}{c}\text { Fruit yield/ } \\
\text { plant }(\mathrm{kg})\end{array}$ & $\begin{array}{c}\text { Fruit yield } \\
(\mathrm{t} / \mathrm{ha})\end{array}$ \\
\hline $\mathrm{V}_{1} \mathrm{P}_{1}$ & 60.67 & $11.20 \mathrm{a}$ & 6.33 & $19.18 \mathrm{a}$ & $64.65 \mathrm{~b}$ & $1.24 \mathrm{a}$ & $35.71 \mathrm{a}$ \\
$\mathrm{V}_{1} \mathrm{P}_{2}$ & 67.33 & $8.63 \mathrm{~cd}$ & 5.57 & $11.44 \mathrm{~d}$ & $62.94 \mathrm{~b}$ & $0.72 \mathrm{~d}$ & $20.57 \mathrm{c}$ \\
$\mathrm{V}_{1} \mathrm{P}_{3}$ & 65.33 & $8.13 \mathrm{~d}$ & 5.60 & $5.57 \mathrm{f}$ & $30.52 \mathrm{f}$ & $0.17 \mathrm{f}$ & $4.86 \mathrm{e}$ \\
$\mathrm{V}_{2} \mathrm{P}_{1}$ & 61.67 & $10.37 \mathrm{ab}$ & 6.37 & $14.62 \mathrm{bc}$ & $54.04 \mathrm{~d}$ & $0.79 \mathrm{~cd}$ & $22.57 \mathrm{c}$ \\
$\mathrm{V}_{2} \mathrm{P}_{2}$ & 66.00 & $10.17 \mathrm{a}-\mathrm{c}$ & 5.67 & $15.67 \mathrm{~b}$ & $68.92 \mathrm{a}$ & $1.08 \mathrm{~b}$ & $28.8 \mathrm{~b}$ \\
$\mathrm{~V}_{2} \mathrm{P}_{3}$ & 66.67 & $9.50 \mathrm{~b}-\mathrm{d}$ & 5.67 & $10.55 \mathrm{~d}$ & $40.76 \mathrm{e}$ & $0.43 \mathrm{e}$ & $12.57 \mathrm{~d}$ \\
$\mathrm{~V}_{3} \mathrm{P}_{1}$ & 61.67 & $10.17 \mathrm{a}-\mathrm{c}$ & 6.17 & $14.60 \mathrm{bc}$ & $52.74 \mathrm{~d}$ & $0.77 \mathrm{~cd}$ & $22.29 . \mathrm{c}$ \\
$\mathrm{V}_{3} \mathrm{P}_{2}$ & 67.33 & $11.07 \mathrm{ab}$ & 5.90 & $13.57 \mathrm{c}$ & $58.95 \mathrm{c}$ & $0.80 \mathrm{c}$ & $22.86 \mathrm{c}$ \\
$\mathrm{V}_{3} \mathrm{P}_{3}$ & 66.00 & $6.43 \mathrm{e}$ & 4.67 & $7.68 \mathrm{e}$ & $23.44 \mathrm{~g}$ & $0.18 \mathrm{f}$ & $5.43 \mathrm{e}$ \\
$\mathrm{F}-\mathrm{test}$ & $n s$ & $* *$ & $\mathrm{~ns}$ & $* *$ & $* *$ & $* *$ & $* *$ \\
$\mathrm{CV} \%$ & 2.47 & 6.78 & 8.85 & 4.81 & 6.71 & 3.92 & 5.35 \\
\hline
\end{tabular}

Means followed by same letter(s) in a column do not differ significantly by LSD

$* *=$ Significant at $1 \%$ level of probability, $n s=$ Not significant; Where, $\mathrm{V}_{1}=\mathrm{BARI}$ Mistimorich $-1, \mathrm{~V}_{2}=$ California Wonder, $\mathrm{V}_{3}=$ Yolo Wonder; $\mathrm{P}_{1}=$ Fine net, $\mathrm{P}_{2}=$ Coarse net, $\mathrm{P}_{3}=$ Open 
in fine net protection system (19.18) while the second highest (15.67) was recorded in California Wonder grown in coarse net protection system. The lowest number of fruit per plant was recorded in BARI Mistimorich1 planted in open field (5.57). Under open field condition, all the varieties produced lower number of fruits and higher number of fruit in fine net protection system. This might be due to having more congenial microclimate and more protection against biotic stress in fine net condition than open field condition.

\section{Individual fruit weight (g)}

Maximum individual fruit weight was found in California Wonder (68.92 g) grown in coarse net protection system followed by BARI Mistimorich-1 (64.65 g) grown in fine net system. On the contrary, minimum individual fruit weight was found in Yolo Wonder (23.44 g) grown in open field. This result was closely related to the findings of Halim and Islam (2013), who found maximum individual fruit weight of $65.2 \mathrm{~g}$ grown under poly house.

\section{Fruit yield /plant (kg)}

Among nine different treatment combinations the maximum fruit yield was found in BARI Mistimorich-1 $(1.24 \mathrm{~kg})$ grown under fine net protection system followed by California Wonder $(1.08 \mathrm{~kg})$ when grown in coarse net protection system. While the fruit yield was minimum in BARI Mistimorich- $1(0.17 \mathrm{~kg})$ in open field condition which was closely followed by Yolo Wonder $(0.18 \mathrm{~kg})$, grown in open field. Result indicated that in open field condition having various biotic and abiotic stresses, plants produced the lowest yield. Islam and Halim (2014) obtained the lowest fruit yield per plant in open field while it was the highest when the plants grown under tunnel cover with polythene and nylon net.

\section{Fruit yield (t/ha)}

Significant variation was observed for fruit yield per hectare due to the interaction effect of varieties and net protection systems (Table 3 ). Fruit yield was maximum $(35.71 \mathrm{t} / \mathrm{ha})$ in $\mathrm{V}_{1} \mathrm{P}_{1}$ (BARI Mistimorich-1when grown in fine net system), followed by California Wonder (28.8 t/ha) when grown under coarse net protection system and the lowest fruit yield (4.86 t/ha) was calculated in $\mathrm{V}_{1} \mathrm{P}_{3}$ (BARI Mistimorich-1 when grown in open field). Result of the study indicated that sweet pepper yield ( $t / h a)$ was lower under open field condition irrespective of varieties. This variation might be attributed due to shade-nets provide physical protection against hail, wind, bird and insect-transmitted virus diseases (Shahak, 2008). Ahemd et al. (2016) opined that reducing the transmitted solar radiation under shading reduces the canopy and air temperatures as well as the transpiration rate in the greenhouses. This consequently increases the water use efficiency and enhances the crop productivity up to $40 \%$.

Pictorial view of fruit of different sweet pepper varieties grown in open field and under net protection system has been displayed in Fig. 1. In case of open field, small sized and deformed fruits were found which were unable to fulfil the consumer preferance. On the contrary under net protection system plant produced better quality fruit viz. smooth skin surface, uniform size and shape, uniform skin color, bigger fruit. Ilic et al. (2017) observed that shade-nets can increase the total yield and improve fruit quality (mass, pericarp thickness and vitamin $\mathrm{C}$ content). They added that shading reduced the appearance of sweet pepper cracking and eliminated sunscalds on sweet pepper fruits and accordingly, increased the marketable sweet pepper production 


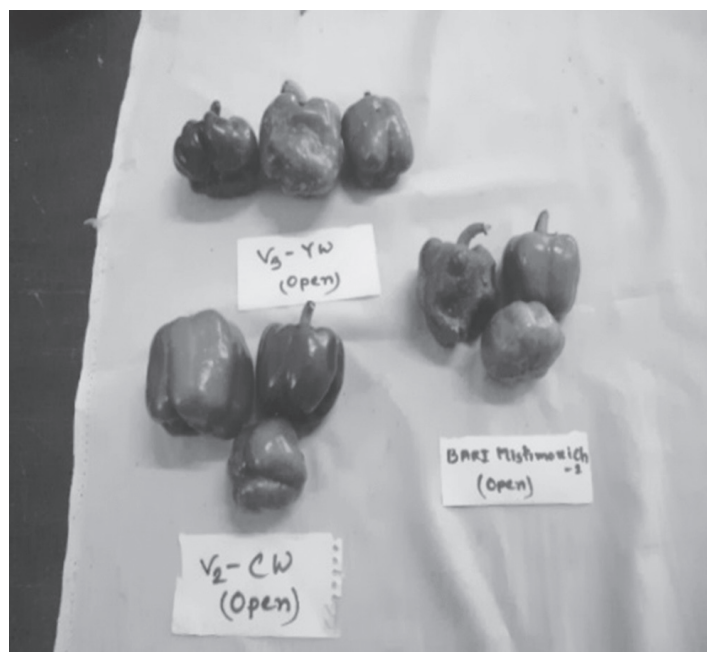

a. Open field

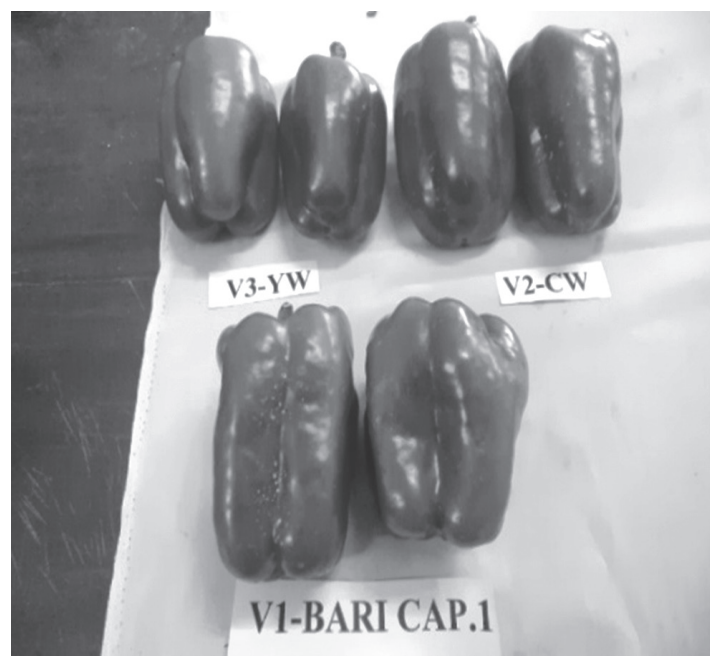

b. net protection system

Fig. 1. Fruits of different sweet pepper varieties in open field and under net protection system

by about $25 \%$ compared to non-shading conditions. So production of sweet pepper under protection system is better than open field in Sylhet region where climatic condition is unpredictable than other part of the country.

The economic analysis of sweet pepper grown under different net protection systems has been presented in Table 4. Plants grown in fine net protection system $\left(\mathrm{P}_{1}\right)$ required the highest total cost compared to coarse net protection system. The lowest total cost was required for open field condition. But benefit cost ratio (BCR) analysis showed that plants grown under the fine net or coarse net protection systems gave the higher gross return than control. BCR was also higher in fine net (5.28) and coarse net (6.75) protection system than open field system (1.64). Among the inputs used, net and bamboo were the expensive which was $64 \%$ of the total cost. To reduce bamboo and net cost expense, the same materials might be used for the next season.

\section{Conclusion}

From the present study, it was found that, California Wonder and BARI Mistimorich-1

Table 4. Benefit cost analysis of different sweet pepper varieties grown under different net systems

\begin{tabular}{lcccccc}
\hline Treatment & $\begin{array}{c}\text { Yield } \\
(\mathrm{t} / \mathrm{ha})\end{array}$ & $\begin{array}{c}\text { Rate/ } \\
\mathrm{kg}(\mathrm{Tk})\end{array}$ & $\begin{array}{c}\text { Gross return } \\
(\text { Tk."000"/ha) }\end{array}$ & $\begin{array}{c}\text { Net return } \\
(\text { Tk."000"/ha) }\end{array}$ & $\begin{array}{c}\text { Cost of } \\
\text { production } \\
(\text { Tk".000"/ha) }\end{array}$ & $\begin{array}{c}\text { Benefit } \\
\text { cost ratio }\end{array}$ \\
\hline Fine net & 26.86 & 140 & 3760.4 & 3049 & 711.4 & 5.28 \\
Coarse net & 24.07 & 140 & 3369.8 & 2870.9 & 498.9 & 6.75 \\
Open Field & 7.62 & 25 & 190.50 & 74.4 & 116.1 & 1.64 \\
\hline
\end{tabular}


performed well under both net protected conditions. Pending further trial it may be said that the above two sweet pepper varieties could be cultivated under both net protection systems in Sylhet region.

\section{Acknowledgements}

The Authors cordially express their appreciation to Krishi Gobeshona Foundation for financial support to conduct this research work under KGF-BKGET $1^{\text {st }}$ call project $(\mathrm{TF}$ 01-C).

\section{References}

Ahemd, H. A., A. A. Al Faraj and A. M. AbdelGhany. 2016. Shading greenhouses to improve the microclimate, energy and water saving in hot regions: a review. Sci. Hortic. 201: 36-45.

Aminifard, M. H., H. Aroiee, A. Ameri and H. Fatemi. 2012. Effect of plant density and nitrogen fertilizer on growth, yield and fruit quality of sweet pepper (Capsicum annum L.). Afr. J. Agric. Res. 7(6): 859866.

Anonymous. 2009. Annual Report 2008-2009. Olericulture Division, Bangladesh Agricultural Research Institute, Gazipur $110 \mathrm{P}$.

Anonymous. 2010. Annual Report 2009-2010. Olericulture Division, Bangladesh Agricultural Research Institute, Gazipur $116 \mathrm{P}$.

Bhatt, R. M., N. K. Srinivasa Rao and N. Anand. 1992. Response of bell-pepper (Capsicum annuиm L.) to irradiance-photosynthesis, reproductive attributes and yield. Indian J. Hortic. 56(1): 62-66.

Boswell, V. R. 1964. Pepper production. In: Spices. (ed.) Longman Scientific Technical, John Willy and Sons Inc. New York 331 P.
Elad, Y., Y. Messika, M. Brand, D. R. David and A. Sztejnberg. 2007. Effect of microclimate on Leveillula taurica powdery mildew of sweet pepper. Phytopathol. 97(7): 813824.

FAO (Food and Agricultural Organization). 1988. Production Year book. Food and Agricultural Organization of the United Nation, Rome, Italy. 42: 190-193.

Greenleaf, W. H. 1986. Pepper Breeding. In: Bassett, M. J. (ed.) Breeding Vegetable Crops. Pp. 67-134. Avi Publishing, Westport, Connecticut.

Halim, G. M. A. and M. S. Islam. 2013. Performance of sweet pepper under protective structrure in Gazipur Bangladesh. Int. J. Environ. 1(1): 1-8.

Islam, M. S. and G. M. A. Halim. 2014. Effect of different tunnel covers on growth and yield of sweet pepper. J. Sylhet Agril. Univ. 1(1): 11-14.

Ilic, Z. S., L. Milenkovic, L.Unic,S. Barac,J. Mastilovic, Z. Kevresan and E. Fallik. 2017. Effect of shading by coloured nets on yield and fruit quality of sweet pepper. Zemdirbyste. 104(1):53-62.

Jeon, H. J. and H. D. Chung. 1982. Effect of shade on the flowering, yield and fruit composition of different red pepper, Capsicum annuum L. cultivars. J. Korean Soc. Hortic. Sci. 23(4): 253-260.

Lal, M., H. S. Kanwar and R. Kanwar. 2014. Impact of spacing and training on seed yield of capsicum, Capsicum annuum $\mathrm{L}$ under protected conditions. Int. J. Farm Sci. 4(3): 42-48.

Mashabela, M. N., K. M. Selahle, P. Soundy, K. M. Crosby and D. Sivakumar. 2015. Bioactive compounds and fruit quality of green sweet pepper grown under different colored shade netting during postharvest storage. J. Food Sci. 80: 2612-2618. 
Paul, T. K. 2009. Technology of sweet pepper production in Bangladesh. PhD Thesis. Dept of Horticulture, BSMRAU, Salna, Gazipur 225 P.

Rashid, M. A., S. Ahmad, G. M. A. Halim and S. N. Alam. 2006. Improved production technology of vegetable crops (In Bengali). Olericulture Division, HRC, BARI, Gazipur 158 P.

Rylski, I. and M. Spiegelman. 1982. Effects of different diurnal temperature combination on fruit set of sweet pepper. Sci. Hortic. 17: 101-106.

Sattar, M. A., M. S. Alam and F. Islam. 2018. Performance of sweet pepper genotypes during late winter. Research Report 20172018, Olericulture Division, HRC, BARI, Gazipur 250 P.

Selahle, K. M., D. Sivakumar, J. Jifon, P. Soundy. 2015. Postharvest responses of red and yellow sweet peppers grown under photoselective nets. Food Chem. 173: 951-956.
Shahak, Y. 2008. Photo-selective netting for improved performance of horticultural crops. A review of ornamental and vegetable studies carried out in Israel. Acta Hortic. 770: 161-168.

Shoemaker, J. S. and B. J. E. Teskey. 1955. Pract. Hortic. John Willey and Sons, Inc. New York $371 \mathrm{P}$.

Wien, H. C., K. E. Tripp, A. R. Harnandez and A. d. Turner. 1989. Abscission of reproductive structures in pepper: causes, mechanism and control. Pp. 150-165. In: Green S. K. (ed.) Tomato and pepper production in the tropics. AVRDC, Taiwan.

Zende, U. M. 2008. Investigation on production techniques in capsicum under protected cultivation. M. Sc. degree. College of Agriculture, Dharwad, University of Agricultural Sci., Dharwad, India. 